\title{
Study of NTF-3 (Neurotrophic Factor 3) Gene Information in Columbidae by In Silico
}

\author{
(Studi Informasi Gen NTF-3 (Neurotrophic Factor 3) Pada Columbidae Secara In Silico) \\ Suprianto*), I Made Budiarsa, Fatmah Dhafir, Ni Kadek Dewi Permatasari, \\ Gusti Ayu Kadek Yunita Safitri \\ Jurusan Pendidikan MIPA, Fakultas Keguruan dan Ilmu Pendidikan, Universitas Tadulako \\ Jin. Soekarno-Hatta, Palu 94148
}

\section{ABSTRACT}

Neurotrophin Factor 3(NTF3) is one of the genes that plays an important role in the regulation of the neural systems of vertebrate animals, this gene has a special function in explaining the survival factors of some vertebrate animals. Based on the information obtained from GenBank, the nucleotide sequence of the NTF-3 gene in several vertebrate animals has been known and some of the data obtained have not been studied further for research purposes in adding information related to the molecular character of the NTF-3 gene, such as the NTF-3 gene in Columbidae. Columbidae is a group of birds that have quite diverse species variations, the number of species in columbidae will be very helpful in obtaining data on comparisons of the genetic character of the NTF3 gene. The purpose of this study was to analyze and describe the information on the NTF-3 gene (Neurotrophic Factor 3) in Columbidae through the in silico approach with computational methods. The NTF3 gene nucleotide sequences in Columbidae showed a fairly high level of similarity to the base sequences. This illustrates the fairly close proximity between each species. Geotrygon Montana is a species of Columbidae which has variations of the Base sequence which is quite different from other species. Evaluation of the model structure shows good stability of each target protein, all evaluation results describe a good structure, meaning that the conformation of each target sequence is in accordance with the sequence, so that the structure that is built has high accuracy with the actual model. The results of this research study can be a special description in explaining the genetic characteristics of several Columbidae species for the purposes of conservation measures or efforts to preserve Columbidae species at the molecular and population genetic levels.

Neurotrophin Factor 3 (NTF-3) merupakan salah satu gen yang berperan penting dalam regulasi sistem saraf hewan vertebrata,gen ini memiliki fungsi khusus dalam menjelaskan survival factor dari beberapa hewan vertebrata. Urutan nukleotida gen NTF-3 pada beberapa hewan vertebrata telah diketahui dan sebagian data yang diperoleh belum dikaji lebih lanjut untuk keperluan penelitian dalam menambah informasi terkait karakter molekuler gen NTF-3, seperti gen NTF-3 pada Columbidae. Famili Columbidae merupakan sekelompok burung yang memiliki variasi jenis yang cukup beragam, jumlah spesies pada Columbidae akan sangat membantu dalam memeroleh data perbandingan karakter genetik gen NTF-3. Tujuan dari penelitian ini adalah untuk menganalisis dan mendeskripsikan Informasi genetik gen NTF-3 pada Columbidae terkait komposisi basa nukleotida serta struktur tiga dimensi protein yang diekspresikan oleh Gen NTF-3 (Neurotrophic Factor 3) pada Columbidae melalui pendekatan in silico. Urutan nukelotida gen NTF-3 pada Columbidae menunjukkan tingkat similaritas urutan basa yang cukup tinggi. Hal ini menggambarkan kedekatan yang cukup dekat antar masing-masing spesies. Geotrygon montana adalah spesies Columbidae yang memiliki variasi urutan basa yang cukup berbeda dengan spesies lainnya. Evaluasi struktur model menunjukkan kestabilan yang baik dari masing-masing proteintarget, seluruh hasil evaluasi menggambarkan struktur yang baik, artinya konformasi masing-masing sekuen target sesuai dengan urutannya, sehingga struktur yang terbangun memiliki akurasi yang tinggi dengan model yang sebenarnya. Hasil kajian penelitian ini dapat menjadi gambaran khusus dalam menjelaskan karakter genetik beberapa spesies Columbidae untuk keperluan tindakan konservasi atau upaya pelestarian spesies Columbidae ditingkat molekuler dan genetika populasi.

Keywords: Columbidae, NTF-3, In Silico.

E-mail: supriantoupick28@gmail.com 


\section{PENDAHULUAN}

Gen Neurotrophin 3 (NTF-3) adalah gen yang mengekspersikan protein Neurotrophin-3 (NT-3) yang memegang peran dalam proses diferensiasi, kelangsungan hidup neuron perifer dan neuron neuropatologis [1] dan gen Neurotrophin-3 (NTF-3) memilki peran penting untuk kelangsungan hidup neuron sensorik dan pembentukan proyeksi neuron keepitel sensorik di telinga bagian dalam embrio serta berkontribusi pada kelangsungan neuron sensorik koklea dan vestibular [2]. Gen NTF-3 telah terbukti mampu mempertahankan fungsi sinapsis dan synaptogenesis. Difisiensi fungsional dari gen NTF-3 telah terbukti menyebakan deficit saraf yang parah, hal tersebut menunjukan bahwa NTF-3 sangat penting kaitannya terhadap kelangsungan hidup dan sebagai saraf akson [3].

NTF-3 merupakan gen yang mengkodekan protein Neurotrophin-3 (NT3) [4]. NT-3 merupakan protein yang berasal dari factor neurotropic yang memiliki peran penting dalam diferensiasi, kelangsunganhidup neuron perifer dan neuropatologis sistem saraf [5-6]. Lebih lanjut Mayeur et al., (2010) [7] menjelaskan bahwa NT-3 berfungsi dalam proses pertumbuhan neuron atau neurogenesis. Protein yang dikodekan oleh gen NTF-3 merupakan kelompok neurotrophin. Neurotropin merupakan keluarga terdekat dariprotein yang diidentifikasi memiliki faktor pertahanan untuk neuron sensorik dan simpatik, mempengaruhi beberapa aspek pertahanan mahluk hidup serta meningkatkan fungsi kerja dari sel neuron baik dalam sistem saraf pusat atau saraf perifer [8]. Keberadaan neurotropin dalam sistem saraf sangat dibutuhkan sebagai Survival Factor, neurotropin pertama yang berhasil ditemukan adalah Nerve Growth Factor [910].

Berdasarkan fungsi gen NTF-3 sebagai Survival Factor peneliti ingin mengkaji lebih lanjut mengenai karakter genetik gen tersebut dalam menjelaskan karakter genetik gen NTF-3 terhadap fungsinya. Informasi mengenai gen NTF-3 masih sangat perlu dikembangkan dengan melihat kurangnya informasi terkait studi gen NTF-3, seperti pada burung keluarga Columbidae. Famili Columbidae merupakan sekelompok burung yang memiliki variasi jenis yang cukup beragam dan memilki persebaran yang tinggi termasuk di Indonesia [11] dan menjadi hal yang menarik untuk dikaji lebih lanjut terkait sifat genetiknya yang beragam, jumlah spesies pada Columbidae akan sangat membantu dalam memeroleh data perbandingan karakter genetik gen NTF-3. Berdasarkan database urutan nukleotida dalam GenBank, spesies Columbidae mempunyai jumlah sampel gen yang lebih banyak dari kelompok jenis burung lainnya, sehingga perbandingan data yang diperlukan akan lebih variatif. Jumlah spesies pada Columbidae akan sangat membantu dalam memeroleh data perbandingan karakter genetik gen NTF-3.

Berkembangnya teknik biologi molekular mengakibatkan karakteristik DNA semakin banyak dapat diungkapkan. Terungkapnya sekuen DNA terutama setelah ditemukannya sekuen DNA dengan tingkat polimorfisme yang tinggi, mendorong penggunaan kajian molekular dalamgenetika populasi [12]. Tujuan dari penelitian ini adalah untuk menganalisis dan mendeskripsikan Informasi genetik gen NTF-3 pada Columbidae terkait komposisi basa nukleotida serta struktur tiga dimensi protein yang diekspresikan oleh Gen NTF-3 pada Columbidae melalui pendekatan in silico. Datayang diperoleh akan sangat membantu dalam melengkapi data terkait informasi penting ditingkat molekuler dan keperluan studi lanjut mengenai gen NTF-3. Perkembangan teknik biologi molekuler telah banyak memberikan kontribusi dalam memperluas kajian molekuler, salah satunya melalui teknik komputasi dengan analisis secara in silico. Analisis ini akan sangat membantu dalam menggambarkan sifat dan karakteristik suatu senyawa atau molekul secara detil [13] untuk dipelajari lebih lanjut mengenai sifat gen NTF-3 sebagai survival factor yang dapat mendukung upaya pelestarian dan konservasi spesies Columbidae ditingkat molekuler dan genetika populasi.

\section{METODE PENELITIAN}

Penelusuran dan pengunduhan sequence gen NTF3 pada Columbidae dari GenBank dengan kode akses EU740378.1, EU740327.1, EU740298.1, EU740274.1 dan EU740273.1 (NCBI-ID) diperlukan sebagai Gen target untukmendapatkan hasil penelitian. Mengunduh sequence protein dari gen NTF-3 pada Columbidae dengan nomor akses ACF34626.1, ACF34575.1, ACF34546.1, ACF34522.1 dan ACF34521.1 berdasarkan hasil Identical Protein dari database gen target. Pensejajaran urutan nukleotida menggunakan ClustalW dibutuhkan untuk memperoleh data perbandingan masing-masing gen 
untuk mengetahui tingkat atau hubungan kekerabatan antar spesies berdasarkan similaritas urutan basa. Menentukan Estimasi Divergensi Evolusioner dianalisis menggunakan MEGA X untuk melihatjarak evolusi masing- masing spesies Columidae. Struktur tiga dimensi protein diprediksi menggunakan software Chimera. Validasi model dilakukan berdasarkan plot ramachandran, ERRAT, verifikasi 3D yang dievaluasi menggunakan SAVES server [14].

\section{HASIL DAN PEMBAHASAN}

Sumber data gen NTF-3 pada Columbidae diperoleh dari hasil penelusuran beberapa sequence di GenBank. Terdapat lima sequence gen NTF-3 pada Columbidae yang diperoleh dari database NCBI, kelima sampel menunjukkan tingkat similaritas yang tinggi dan beberapa karakter hampir sama berdasarkan identitas, panjang sequence, query cover dan max score (Tabel. 1).

Tabel 1. Profil gen NTF-3 pada Columbidae

\begin{tabular}{|c|c|c|c|c|c|c|c|}
\hline No & Deskripsi & MaxScore & Lengt & $\begin{array}{l}\text { Query } \\
\text { Cover }\end{array}$ & E Value & Identity & Accession Number \\
\hline 1 & $\begin{array}{c}\text { Treron vernans neurotrophin } \\
3 \text { (NTF3) gene, exon } 2 \text { and } \\
\text { partial cds }\end{array}$ & 1341 & $728 \mathrm{bp}$ & $100 \%$ & 0.0 & $100 \%$ & EU740378.1 \\
\hline 2 & $\begin{array}{c}\text { Otidiphaps nobilis } \\
\text { neurotrophin } 3 \text { (NTF3) } \\
\text { gene, exon } 2 \text { and partial } \\
\text { cds }\end{array}$ & 1253 & $728 \mathrm{bp}$ & $100 \%$ & 0.0 & $97,66 \%$ & EU740327.1 \\
\hline 3 & $\begin{array}{l}\text { Columba livia neurotrophin } \\
3 \text { (NTF3) gene, exon } 2 \text { and } \\
\text { partial cds }\end{array}$ & 1253 & $728 \mathrm{bp}$ & $100 \%$ & 0.0 & $97,66 \%$ & EU740273.1 \\
\hline 4 & $\begin{array}{c}\text { Columbina passerina } \\
\text { neurotrophin } 3 \text { (NTF3) } \\
\text { gene, exon } 2 \text { and partial } \\
\text { cds }\end{array}$ & 1236 & $728 \mathrm{bp}$ & $100 \%$ & 0.0 & $97,25 \%$ & EU740274.1 \\
\hline 5 & $\begin{array}{c}\text { Geotrygon montana } \\
\text { neurotrophin } 3 \text { (NTF3) } \\
\text { gene, exon } 2 \text { and partial } \\
\text { cds }\end{array}$ & 1214 & $711 \mathrm{bp}$ & $97 \%$ & 0.0 & $97,33 \%$ & EU740298.1 \\
\hline
\end{tabular}

Tabel 2. Komposisi Basa Gen NTF 3 masing-masing Spesies

\begin{tabular}{cccccc}
\hline No & Spesies & Adenin $(\mathrm{A})$ & Sitosin $(\mathrm{C})$ & Guanin $(\mathrm{G})$ & Timin $(\mathrm{T})$ \\
\hline 1 & Treron vernans & $246 \mathrm{bp}$ & $158 \mathrm{bp}$ & $164 \mathrm{bp}$ & $159 \mathrm{bp}$ \\
2 & Otidiphaps nobilis & $245 \mathrm{bp}$ & $257 \mathrm{bp}$ & $164 \mathrm{bp}$ & $162 \mathrm{bp}$ \\
3 & Columba livia & $246 \mathrm{bp}$ & $155 \mathrm{bp}$ & $164 \mathrm{bp}$ & $163 \mathrm{bp}$ \\
4 & Columbina passerina & $249 \mathrm{bp}$ & $153 \mathrm{bp}$ & $161 \mathrm{bp}$ & $165 \mathrm{bp}$ \\
5 & Geotrygon montana & $246 \mathrm{bp}$ & $159 \mathrm{bp}$ & $157 \mathrm{bp}$ & $157 \mathrm{bp}$ \\
\hline
\end{tabular}

Pensejajaran kelima urutan nukleotida gen NTF-3 pada Columbidae dilakukan berdasarkan sistem pensejajaran ClustalW pada Bioedit (Gambar 1). Penyelarasan sequence digunakan untuk mengoptimalkan penjajaran, jumlah substitusi dasar antara urutan yang ditunjukkan [15]. Urutan nukleotida yang disejajarkan terdiri dari $1214 \mathrm{bp}$ $1341 \mathrm{bp}$, terdapat persamaan urutan yang sangat menonjol. Selain itu perbedaan urutan basa gen NTF-
3 pada Columbidae ditunjukkan oleh spesies Geotrygon montana, urutan basa ke 712 hingga 728 (Gambar 1) menjelaskan adanya perbedaan urutan basa gen target. Secara keseluruhaan berdasarkan analisis alignment letak perbedaan urutan basa gen NTF-3 dari masing masing spesies terletak pada bagian yang tidak diwarnai dan berada di urutan 9, 10, 12, 20, 23, 69, 87, 98, 138, 156, 165, 171, 182, 197, 202, 228, 291, 300, 320, 330, 338, 360, 369, 381, 399, 408, 
411, 531, 546, 564, 588 dan 688 (Gambar 1). Perbedaan ini menjadi indikasi adanya perbedaan karakter setiap spesies Columbidae meskipun dengan gen yang sama, sehingga perbedaan tersebut diprediksi akan mempengaruhi bentuk struktur tiga dimensi protein yang dihasilkan dari gen target. Tingkat similaritas tersebut dapat dilihat sesuai dengan hasil pensejajaran masing-masing sequence. Geotrygon montana memiliki jumlah base pair paling sedikit diantara keempat spesies, hanya selisih 17 base pair.
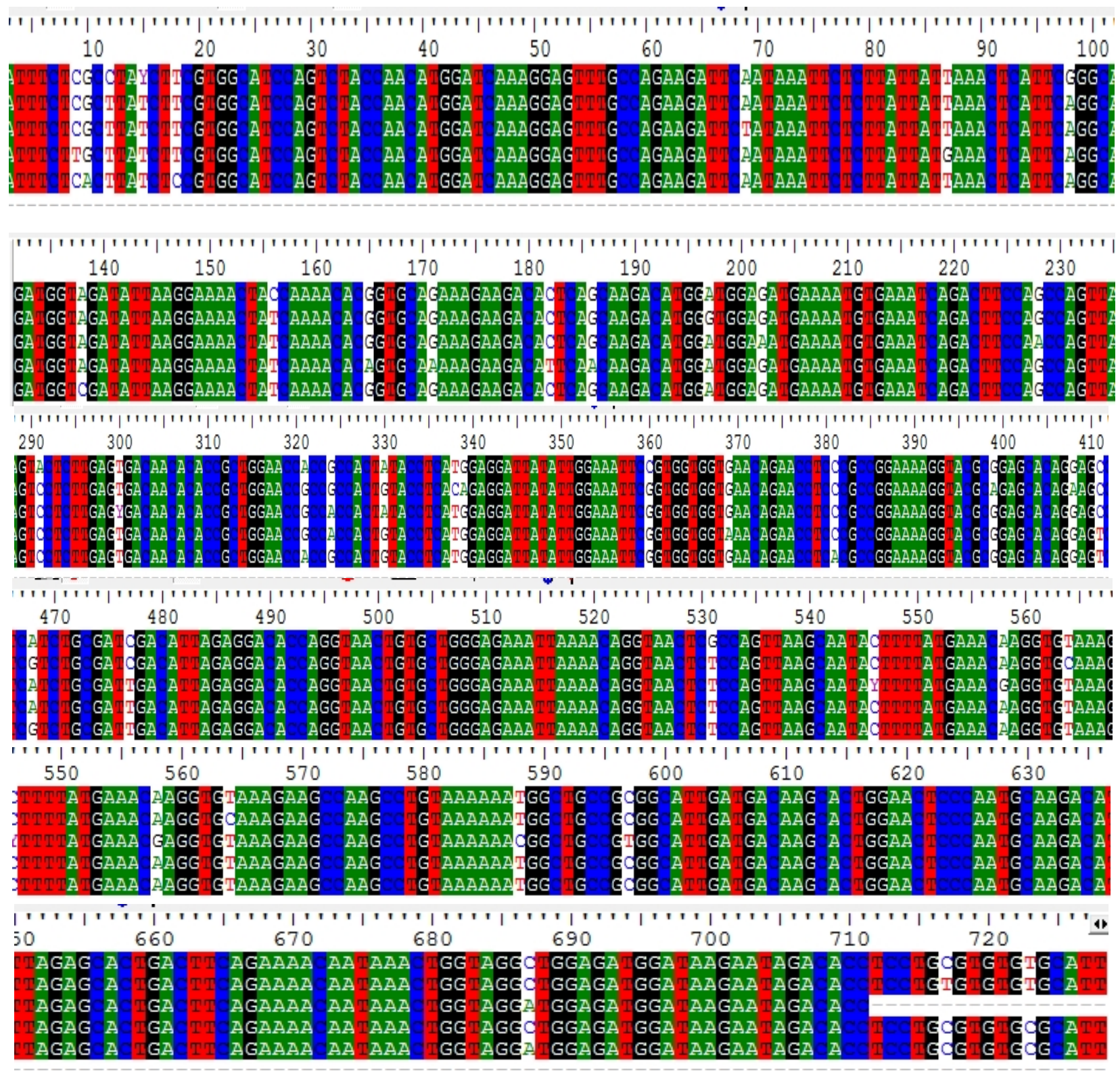

Gambar 1. Hasil Pensejajaran sequence menggunakan ClustalW tool pada Bioedit

\section{Estimasi Divergensi Evolusioner}

Perubahan evolusi berbasis urutan nukleotida terkait dengan peristiwa mutasi, insersi, delesi dan inversi yangmenyebabkan perubahan-perubahan pada tingkat gen (nukleotida), sehingga terjadinya microevolution [16]. Semakin banyak variasi genetik yang ada dalam suatupopulasi, semakin besar peluang terjadinya evolusi, kemungkinan beberapa bentuk akan berubah frekuensi. Ada empat proses perubahan frekuensi gen yaitu mutasi, migrasi, drift, dan seleksi alam [17].

Kedekatan atau jarak evolusioner dua organism atau lebih dapat diperkirakan dari tingkat kesamaan urutan asam amino proteinnya, serta membandingkan urutan basa DNA dan RNAnya. Sehingga ampuh untuk membangun hubungan evolusioner [18]. 
Kesamaan antara urutan nuleotidaadalah bukti bahwa mereka berasal dari urutan leluhur yang sama dan kode genetik yang sama dan 20 asam amino yang sama tidak dapat memiliki asal yang independen serta kemiripan urutan nukleotida dalam DNA atau urutan asam amino dalam protein tidak dapat berasal dari independen [17]. Berdasarkan hasil penyejajaran terlihat bahwa setiap spesies memiliki variasi urutan yang berbeda diperlihatkan oleh adanya perbedaan basa di daerah tertentu pada sequence masing-masing spesies burung dari keluarga columbidae. Nilai matriks jarak genetik yang nilainya semakin rendah memiliki arti bahwa hubungan kekerabatannya semakin dekat [19]. Faktor yang mempengaruhi perbedaan genetik antar spesies biasanya dipengaruhi oleh beberapa faktor seperti genetic drift dan natural selection [20].

Semakin tinggi nilai jarak genetik maka semakin jauh hubungan kekerabatannya, begitu juga dengan sebaliknya semakin rendah nilai jarak genetik maka semakin dekat hubungan kekerabatannya [21]. Estimasi divergensi evolusioner diantara kelima sequence gen NTF-3 pada Columbidae menujukkan jarak evolusi pasangan basa antar organisme. Kelima spesies menggambarkan jarak evolusi yang variatif, setiap jarak dipengaruhi oleh komponen basa yang menyusun gen setiap spesies. Jarak antara Treron vernans dengan Otodiphaps nobilis adalah 0,0224 dan jarak antara Columba livia dan Columba passerina adalah 0,0225. Jarak terdekat ditunjukkan oleh Treron vernans dengan Otodiphaps nobilis dan jarak terjauh ditunjukkan oleh C. passerina dan Geotrygon montana. Keseluruhan estimasi divergensi evolusioner diantara sequence dapat dilihat pada Tabel 2.

Tabel 3. Estimasi Divergensi Evolusioner diantara Sequence

\begin{tabular}{ccccc}
\hline Treron & & & & \\
vernanas & & & & \\
$\begin{array}{c}\text { Otidiphans } \\
\text { nobilis }\end{array}$ & 0.0224 & & & \\
$\begin{array}{c}\text { Geotrygon } \\
\text { Montana }\end{array}$ & 0.0231 & 0.0244 & & \\
$\begin{array}{c}\text { Columbia } \\
\text { passerine }\end{array}$ & 0.0267 & 0.0266 & 0.0230 & \\
$\begin{array}{c}\text { Columba } \\
\text { livia }\end{array}$ & 0.0225 & 0.0224 & 0.0215 & 0.0210 \\
\hline
\end{tabular}

Visualisasi Struktur Model 3D Protein Gen NTF3

Salah satu cara untuk mempelajari sifat dan fungsi biokimia protein adalah mempelajari struktur protein [22]. Prediksi struktur tiga dimensi protein pada penelitian ini menggunakan Chimera untuk visualisasi struktur protein berdasarkan format PDB, kelima struktur yang terbangun diperoleh dari penggunaan template 3buk.1A. (PDB-ID), digunakan untuk membangun struktur protein dari gen NTF-3 dengan lima spesies berbeda yang merupakan kelompok burung dari keluarga columbidae. Similaritas struktur sangat terlihat jelas, beberapa daerah lekukan pada struktur menggambarkan kemiripan antar protein. Struktur tiga dimensi protein dari spesies Geotrygon montana menunjukkan sedikit perbedaan pada daerah strand, kejelasanperbedaan dapat dilihat pada Gambar 2.
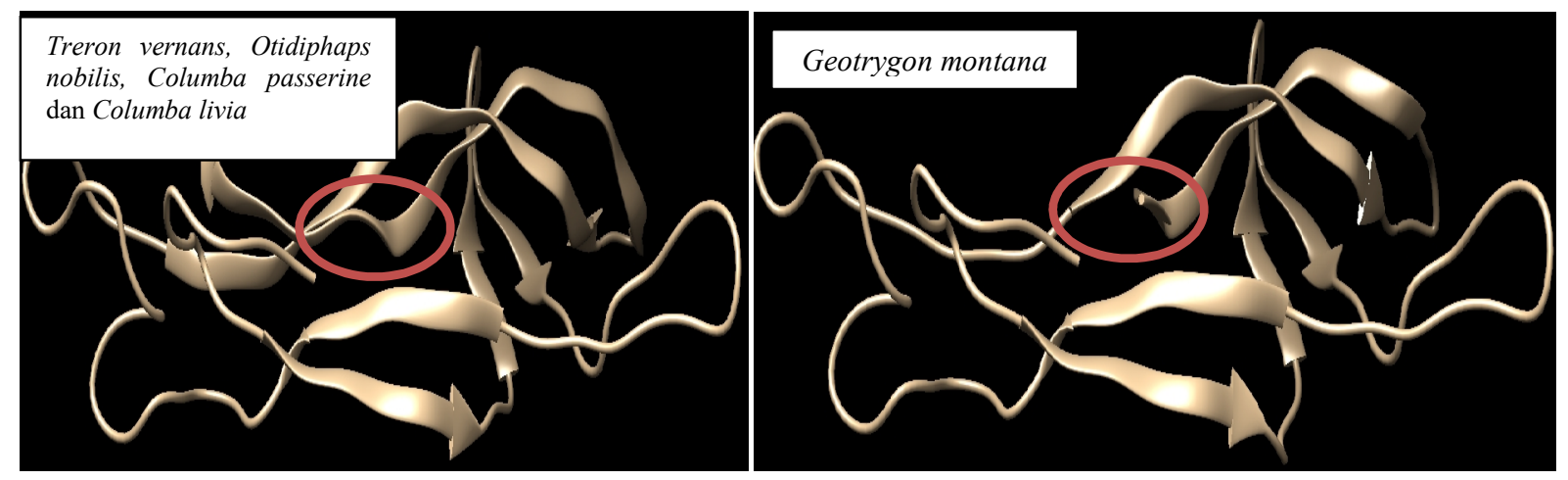

Gambar 2. Perbedaan Struktur 3D Protein dari Gen NTF-3 pada Columbidae

Salah satu faktor yang mempengaruhi bentuk struktur protein adalah ikatan antar atom yang saling terhubung antar satu sama lain. Struktur protein yang terbangun dipengaruhi oleh bentuk ikatan yang membentuk rantai punggung. Struktur protein dipertahankan melalui dua ikatan kuat dan lemah. Ikatan kuat yaitu ikatan peptida dan ikatan disulfida, sedangkan ikatan lemah yaitu ikatan hidrogen, ikatan 
hidrofobik, dan ikatan elektrostatik atau ikatan garam. Ikatan hidrogen terbentuk antara residu pengikat yang terdapat pada rantai samping ikatan peptida asam amino dan ikatan yang terbentuk antara atom hidrogen dengan oksigen ikatan peptida sendiri. Ikatan hidrogen penting untuk mempertahankan struktur primer [23].

Hasil penilaian struktur protein yang diperoleh menggambarkan kualitas struktur yang diharapakan, residu asam amino tersebar didaerah yang diinginkan sesuai analisis Proscheck menggunakan SAVES server. Daerah dengan arah panah berwarna kuning menggambarkan struktur beta, daerah seperti benang panjang berwarna kuning menggambarkan struktur coil dan gambar kuning berbentuk zig zag menggambarkan struktur helix. Struktur yang terbangun membentuk struktur sekunder protein berupa strands atau lembaran beta dan coil [22]. Analisis komputasi menunjukkan hanya terdapat dua struktur yang membangun model tanpa struktur helix (Gambar 3). Estimasi eksesbilitas struktur model memiliki dua wilayah penting yang menyebabkan kestabilan struktur target, diperoleh berdasarkan residu asam amino pada allowed region dan favoured region mendominasi struktur model. Hasil analisis menggambarkan bahwa sebaran residu asam amino kelima struktur model yang terbangun dari masing-masing sekuen pada dissalowed region adalah $0 \%$, sehingga hal tersebut menggambarkan bahwa model yang terbangun mendekati struktur yang sebenarnya.

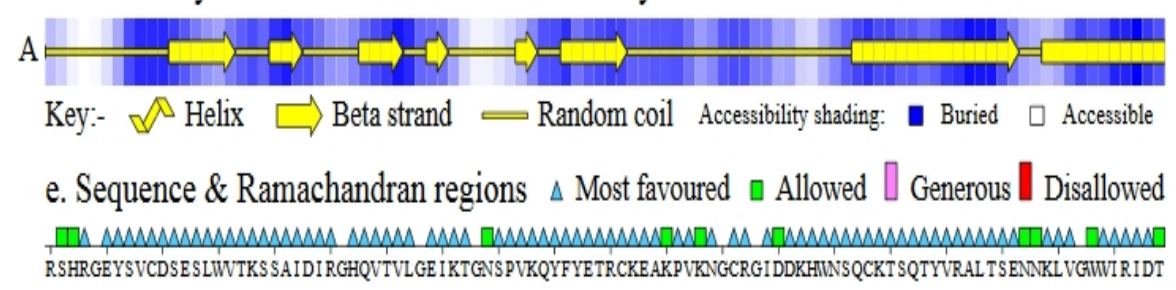

Treron vernans, Otodiphaps nobilis, Columba livia dan Columbina passerina

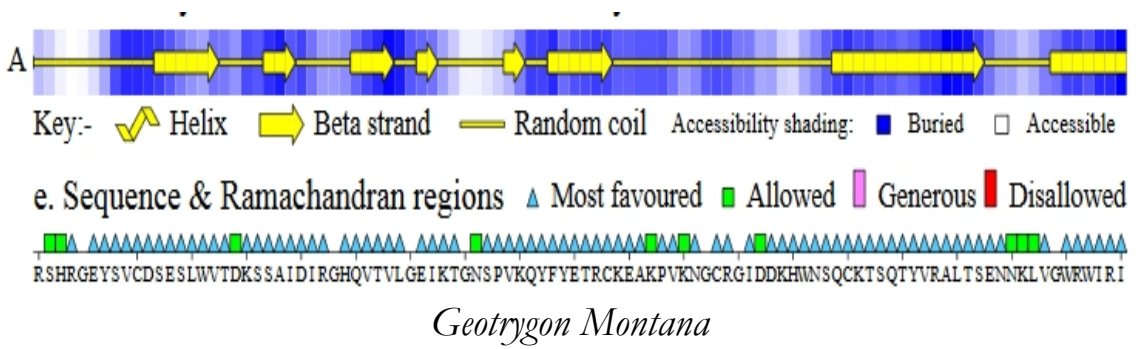

Gambar 3. Estimasi Aksestibilitas Struktur

\section{Penilaian Struktur Model}

Penilaian struktur model yang terbangun dapat dijelaskan berdasarkan sebaran residu asam amino pada ramachandran plot, hal tersebut akan menjelaskan beberapa daerah yang disukai (favoured region), daerah yang diperbolehkan (allowed region) dan daerah yang tidak diperbolehkan (disallowed region). Distribusi asam aminosuatu protein pada tiap daerah tersebut dalam ramachandran plot dapat menggambarkan kestabilan konformasi hingga kualitas struktur protein [24]. Analisis ramchandran plot membantu dalammenjelaskan stabilitas struktur protein yang telah dibangun. Kestabilan suatu struktur menunjukan kualitas protein untuk dikembangkan lebih lanjut, misalnya sebagai vaksin. Kualitasstruktur protein yang diteliti memiliki kualitas yang baik sebagai kandidat vaksin gangguan saraf karena sejumlahresidu asam amino pada daerah disukai (favoured region) lebih dari $70 \%$ dengan persentase residu didaerah tidak disukai (outlier) 0,0\% [25-26]. Tingginya persentase daerah yang disukai dan rendahnya persentase daerah yang tidak disukai menunjukkan bahwa struktur protein yang terbangun pada penelitian memiliki sejumlah konformasi asam amino yang baik, sehingga pembentukkan sudut torsi phi- $\varphi$ dan psi- $\psi$ dalam struktur protein memiliki bentuk yang tepat. Sudut torsi menggambarkan rotasi polipeptida dari dua ikatan yang dibentuk oleh atom $\mathrm{C} \alpha$, yaitu sudut torsi phi $(\varphi)$ dan sudut torsi psi $(\psi)$ [27-28]. Penilaian ramachandran plot dapat dilihat pada Tabel 3. 
Tabel 3. Penilaian Ramachandran Plot Menggunakan SAVES Server

\begin{tabular}{ccccc}
\hline No & Sampel & Favoured Region & Allowed Region & Disallowed Region \\
\hline 1 & Treron vernans & $89,4 \%$ & $10,6 \%$ & $0,0 \%$ \\
2 & Otodiphaps nobilis & $88,5 \%$ & $11,5 \%$ & $0,0 \%$ \\
3 & Columba livia & $88,5 \%$ & $11,5 \%$ & $0,0 \%$ \\
4 & Columba passerina & $88,5 \%$ & $11,5 \%$ & $0,0 \%$ \\
5 & Geotrygon montana & $90,1 \%$ & $9,9 \%$ & $0,0 \%$ \\
\hline
\end{tabular}

\section{KESIMPULAN}

Berdasarkan analisis urutan nukelotida gen NTF-3 pada Columbidae menunjukkan tingkat similaritas urutan basa yang cukup tinggi. Hal ini menggambarkan kedekatan yang cukup dekat antar masing-masing spesies. Geotrygon montana adalah spesies Columbidae yang memiliki variasi urutan Basa yang cukup berbeda dengan spesies lainnya. Evaluasi struktur model menunjukkan kestabilan yang baik dari masing-masing protein target, seluruh hasil evaluasi menggambarkan struktur yang baik, artinya konformasi masing-masing sekuen target sesuai dengan urutannya, sehingga struktur yang terbangun memiliki akurasi yang tinggi dengan model yang sebenarnya. Hasil penelitian ini menjelaskan karakter beberapa spesies Columbidae ditingkatmolekuler yang sangat berperan penting dalam menyediakaninformasi dasar terkait studi lanjut.

\section{DAFTAR PUSTAKA}

[1] M. F. Rahman, A. Kasim, M. L. Djirimu \& I. M. Budiarsa, Analisis In-Silico Struktur Tiga Dimensi Reseptor Trk A dan Trk B Protein Neurotrophin 3 Pada Gallus gallus ( Chicken ), vol. 12, no. 2, pp. 7884, 2020.

[2] G. Wan, M. E. Gómez-Casati, A. R. Gigliello, M. Charles Liberman \& G. Corfas, Neurotrophin-3 regulates ribbon synapse density in the cochlea and induces synapse regeneration after acoustic trauma. ELife. pp. 1-35, 2014.

[3] Y. M. J. Lin, I. L. Hsin, H. S. Sun, S. Lin, Y. L. Lai, H. Y. Cheng, T. Y. Chen, Y. P. Chen, Y. T. Shen, H. M. Wu, NTF3 Is a Novel Target Gene of the Transcription Factor POU3F2 and Is Required for Neuronal Differentiation. Molecular Neurobiology, vol. 55, pp. 8403-8413, 2018.

[4] P.C. Maisonpierre, B.M.M. Le, R. Espinosa, N.Y. Ip, L. Belluscio, D.L.S.M. Monte, S. Squinto, M.E. Furth, \& G. D. Yancopoulos, Human and Rat Brain-Derived
Neurotrophic Factor and Neurotrophin-3: Gene Structures, Distributions, and Chromosomal Localizations. Genomics. vol. 10, no. 3, pp. 558-568, 1991.

[5] L. M., Maness, A. J. Kastin, J. T. Weber, W. A. Banks, B. S. Beckman, \& J. E. Zadina, The neurotrophins and their receptors: structure, function, and neuropathology. Nenroscience and Biobehavioral Reviews, vol. 18, no. 1, pp. 143-159, 1994.

[6] E. J. Nestler, S.E. Hyman, and R.C. Malenka, Molecular neuropharmacology: a foundation for clinical neuroscience 2ndedition, USA: McGraw-Hill, 2009.

[7] S. Mayeur, M. Silhol, E. Moitrot, S. Barbaux, C. Breton, A. Gabory, D. Vaiman, I. Dutriez-Casteloot, I. Fajardy, A. Vambergue, L. Tapia- Arancibia, B. Bastide, L. Storme, C. Junien, D. Vieau, J. Lesage, Placental BDNF/TrkB Signaling Systemis Modulated by Fetal Growth Disturbances in Rat and Human. Placenta, 2010.

[8] L. F. Reichardt, Neurotrophin-regulated signalling pathways. Philos Trans R Soc Lond B Biol Sci 361, vol. 1473, pp. 1545-1564, 2006.

[9] R. Levi-Montalcini, The nerve growth factor 35 years later. Science. vol. 4, pp. 1154-1162, 1987.

[10] E. M. Shooter, Early days of the nerve growth factor proteins.Annu. Rev. Neurosci, vol. 24, pp. 601-629, 2001

[11] J. S. Walker, Geographical patterns of threat among pigeons and doves (Columbidae). Oryx, vol. 41, no. 3, pp. 289-299, 2007.

[12] I. M. Budiarsa, \& J. Situmorang, Diversitas Genetik dan Filogeni Burung Maleo (Mavrocephalon Maleo S. Muller) berdasarkan Sekuen Gen Rdpi Nukleus dan Gen Nd2 Mitokondria. Disertasi Fakultas Biologi UGM (Tidak Dipublikasikan: Yogyakarta, 2011.

[13] Suprianto., M. Trianto, N. Alam, \& Kirana, , Karakter Morfologi dan Analisis Daerah Conserved Gen Elongation Factor $1 \alpha$ (EF1 $\alpha)$ pada Lepidotrigona terminata. Metamorfosa: Journal of Biological Sciences, vol 7, no. 2, pp. 30-39, 2020.

[14] K. Pramanik, P. K. Ghosh, S. Ray, A. Sarkar, S. Mitra \& T. K. Maiti, An in silico structural, functional and 
phylogenetic analysis with three dimensional protein modeling of alkaline phosphatase enzyme of Pseudomonas aeruginosa. Journal of Genetic Engineering and Biotechnology. vol. 15, pp. 527-537, 2017.

[15] P. Hore, S. Nahar, M. Hasampura \& B. Tanti, Phylogenetic Analysis and Homology Modelling of Betaine Aldehyde Dehydrogenase - An Aroma Producing Protein in Rice (Oryza Sativa L.). International Journal of Multidisciplinary Approach and Studies, vol. 4, no. 3, pp. 139, 2017.

[16] I. W. Karmana, Kajian evolusi berbasis urutan nukleotida. Gane Ç Swara, vol. 3, no.3, pp. 75-81, 2009.

[17] F. M. Wuketits \& F. J. Ayala, Handbook of Evolution, Vol. 2: The Evolution of Living Systems (Including Hominids). Wiley-VCH Verlag GmbH \& Co. KGaA, Weinheim, 2005.

[18] J. N. Avery, form A Tion Theor Y And E Vol Ution.Singapore: World Scientific Publishing Co. Pte. Ltd, 2003.

[19] Nurkholidah, Karakterisasi dan Berkoding DNA Globba autrosanguinea Teijsm. \& Binn. (Zingiberaceae) Aksesi Kalimantan. Skripsi Sarjana Biologi. Universitas Islam Negeri Syarif Hidayatullah: Jakarta, 2019.

[20] R. Freeland, Molecular Ecology. England (GB): John Wiley \& Sons. Ltd, 2005.

[21] V. Aprilyanto \& L. Sembiring, Filogenetika Molekuler: Teori dan Aplikasi. Yogyakarta, Innosain, 2015.

[22] H. Wijaya. \& F. Hasana, Prediksi Struktur Tiga Dimensi Protein Allergen Pangan Dengan Metode Homologi Menggunakan Program SWISS MODEL. Biopropal Industri, vol. 7, no. 2, pp. 83-94, 2016.

[23] Sugiyono, Kimia Pangan. Universitas Negeri Yogyakarta: Yogyakarta, 2004.

[24] R. Kurniasih, Struktur Prediksi dan Identifikasi Substrat Spesifik Lakase Isolat Lokal Neorsporacrassaina CC F226. Thesis Sekolah Pascasarjana Tidak Dipublikasikan. Institut Pertanian Bogor: Bogor, 2018.

[25] S. C. Lovell, I. W. Davis, W. B. Arendall Ill, P. I. W de Bakker, J. M. Word, M. G. Prisant, J. S. Richardson \& D. C. Richardson, Structure Validation By C alpha Geometry: Phi,Psi and C beta Deviation. Proteins: Structure, Function \& Genetics, vol. 50, pp. 437-450, 2003.

[26] F. Amelia \& Iryani, Comparrative Modelling Protein Vaksin NA BTB H5N1 Menggunakan SWISSMODEL.Jurnal Sains dan Teknologi, vol. 4, no. 2, pp. 65-69, 2012.

[27] R. V. Mannige, J. Kundhu, S. Whitelam, The ramachandran number: an order parameter for protein geometry. PLOS one. vol. 20016, no. 4, pp. 1- 14, 2016.
[28] S. Ramachandran, P. Kota, F Ding, N. Dokholyan, Automated minimization of steric clashes in protein structures. vol.79, no. 1, pp. 261- 270, 2011. 